\title{
AN UNPUBLISHED SPECIMEN DAYS MANUSCRIPT FRAGMENT
}

\author{
Ed Folsom and Kendall ReED
}

In 1902, G. P. Putnam's Sons issued The Complete Writings of Walt Whitman, a ten-volume set prepared under the editorial supervision of Whitman's literary executors - Richard Maurice Bucke, Thomas B. Harned, and Horace L. Traubel. This set was published in a number of different forms, each with different paper and binding. Five hundred numbered sets of "The Book-Lover's Camden Edition" were manufactured; three hundred numbered sets were issued in the "Paumanok Edition," with color plates; three hundred of "The Collector's Camden Edition"; and two hundred numbered full-leather sets of "The Connoisseur's Camden Edition." What is most notable, however, is that a special "Author's Autograph Edition" was issued in a limited run of ten sets, and an "Author's Manuscript Edition" in thirty-two sets. These were very special publications indeed, because each set contained an actual Whitman manuscript, authenticated as such by the executors, with a notarized statement dated May 19, $1902 .{ }^{1}$

It is not known today how many of the forty-two Autograph and Manuscript Editions are accounted for, and, of those, how many have the original Whitman manuscript still tipped-in in one of the volumes. What we do know, however, is that forty-two important Whitman manuscripts were distributed to buyers of these sets at the beginning of the twentieth century, and many are now lost.

One of those manuscripts is in an Author's Manuscript Edition owned by Kendall Reed. This set is numbered "19," and it contains an early manuscript of part of what came to be, first, an article in The Critic (May 7, 1881) called "My Late Visit to Boston," and then, in 1882, a part of Specimen Days called "A Week's Visit in Boston." Scholars have not worked much with Whitman's prose revisions, and manuscripts like this one demonstrate that a great deal remains to be learned by examining Whitman's careful reworkings of his prose descriptions. Only recently have scholars begun to take Whitman seriously as an accomplished prose writer, and, as studies of his prose books and essays continue to emerge, his remaining prose manuscripts will become an increasingly important resource. 


\section{Here is a transcription of the manuscript:}

Though I staid only Then I lingered a week in Boston- but $I$ felt pretty well (the mood propitious, my paralysis lulled,) - went around everywhere and saw all that was to be seen, especially human beings. It is a theory of mine that occasionally there eomes is vouchsafed to us a one sudden hour, day, moment (opens quietly like a bud or pod) when you we clearly see things, perhaps the people and places familiar for years, now realised for the first. I apply this to scenery, persons, works of art, and all. This time my theory had its hour or day in Boston. The immense material growth, commerce, finance, commission stores - the plethora of goods - the crowded streets and sidewalksare made of course the first surprising show and faets. In a trip

In Specimen Days, this is how the passage appears, significantly pared down:

Then I lingered a week in Boston - felt pretty well (the mood propitious, my paralysis lull'd) - went around everywhere, and saw all that was to be seen, especially human beings. Boston's immense material growth-commerce, finance, commission stores, the plethora of goods, the crowded streets and sidewalks-made of course the first surprising show. (PW 1:264)

As with so many Whitman materials, there is a need for a census of the Author's Autograph and Manuscript Editions and the actual Whitman manuscripts contained therein.

\section{The University of Iowa}

\section{NOTES}

1 See Joel Myerson, Walt Whitman: A Descriptive Bibliography (Pittsburgh: University of Pittsburgh Press, 1993), 415-417.

2 Floyd Stovall, ed., Prose Works 1892 (New York: New York University Press, 1963), 1:264-265. Abbreviated $P W$. 